\title{
The Factors Influencing Economic Efficiency of the Hospital Bed Care in Terms of the Regional Allowance Organizations ${ }^{1}$
}

\author{
Ivana Vaňková, Iveta Vrabková
}

\begin{abstract}
This paper aims to provide an efficiency evaluation of selected hospital bed care providers during years $2010-2012$ with respect to selected factors: The size of the hospital establishment according to number of beds, number of hospitalized patients, the average length of stay per a patient in care, total staff cost calculated per bed, total revenues calculated per bed, and total costs calculated per bed. For this purpose, hospitals providing primarily acute bed care were chosen. From the legal point of view, they are allowance organizations of a particular region. The evaluation concerns both allocative efficiency and technical efficiency. The allocative efficiency is treated from the proper algorithm point of view and it compares total costs calculated per bed with total revenues calculated per bed. A method denominated Data Envelopment Analysis was applied for the calculation of the technical efficiency of units. To be more specific, it was input-oriented model with constant returns to scale (CCR). The input parameters involve the number of beds, the average length of stay and costs per day of stay. Output parameters were as follows: Bed occupancy in days and the number of hospitalized patients. The data published by the Institute of Health Information and Statistic of the Czech Republic and by ÚFIS system (the Data Base of Ministry of Finance of the Czech Republic) were used as the source of data. The evaluation implies that only three hospitals were economically-effective: Silesian Hospital in Opava, Hospital Jihlava, and TGM Hospital Hodonín. The most significant factor influencing the efficiency was determined - the average length of stay.
\end{abstract}

Key words: Health services, hospitals, in-patient care, efficiency, Data Envelopment Analysis model.

JEL Classification: C10, C67, I10, I12

\footnotetext{
${ }^{1}$ The research was created under SGS project (SP2014/74, Models of Evaluation of Efficiency and Quality of In-patient Care in Hospitals), Faculty of Economics, VŠB - Technical University of Ostrava and was supported by the European Social Fund within the project CZ.1.07/2.3.00/20.0296.

${ }^{2}$ Department of Public Economics,VŠB - Technical University of Ostrava, Sokolská 33, 70121 Ostrava, Czech Republic; ivana.vankova@vsb.cz; iveta.vrabkova@vsb.cz
} 


\section{Introduction}

Economic results, rate of occupancy, staff base, financing labor-intensive therapeutic processes, and also capital investments are just some of the problems of hospitals providing bed care in the Czech Republic. This regards the long-term and deepening problems in the area of hospital bed care, which point to inefficiency and weak spots of this health services subsystem. Therefore, it is logical that hospital bed care efficiency in the Czech Republic deserves attention of not only theorists', but first and foremost of the management responsible for this subject or that of the state.

The effort of the state to deal with the problems associated with low efficiency of health services is looked at in numerous modified conceptions which do not offer any specific solutions, though. Darmopilová (2012) claims that every effort to reform the health care system fails in the Czech Republic and that rather diverse, more or less well-thought-out parametric changes occur. The governmental National programme of reforms of the Czech Republic 2012 can be considered an example.

On the other hand, the Public Service Agreements national project of the United Kingdom published in 1998 that aims to increase efficiency of public services, health services included, and in this way to contribute to effectiveness of national strategies, is an example of the system solution related to increasing the efficiency of health services.

The complex evaluation of system efficiency of the national public health and also of individual units can be implemented according to the evaluating framework of the input-output model $4 \mathrm{E}$ (Economy, Efficiency, Effectiveness, Equity), or according to the extended productive model of efficiency (Vaňková, Vrabková, 2013). The extended productive model itself, besides $4 \mathrm{E}$, involves external impulses which are influenced by the socio-economic situation stimulating particular needs of society (Dooren, Bouckaert and Halligan, 2010). According to Flynn (2012), efficiency of health services is affected by four elements - Target and national standards, Inspection and regulation, Published performance information, and direct intervention from the centre.

In spite of the fact that efficiency is one part of the unit efficiency, it can be stated that it comprises of the core of the efficiency, process, institution and even system. Even though in case of interpreting the efficiency it is always the relationship between inputs and outputs of production or individual processes, and the economy and productivity are starting points. Some economists (e.g. Hollingsworth, 2008; Dooren, Bouckaert and Halligan, 2010) distinguish two types of efficiency, namely the technical and allocative efficiency.

The aim of this article is to verify the influence of the selected factors on the efficiency results of providers of hospital bed care in terms of regional allowance organizations in years $2010-2012$.

To achieve the aim, it was necessary to choose the factors which were possible to verify within the technical and allocative efficiency evaluation - the size of a hospital establishment according to number of beds, number of hospitalized patients, the average length of stay per a hospitalized patient, total staff cost calculated per bed, total revenues calculated per bed, total costs calculated per bed. 
The evaluation works on the assumption that economically efficient hospital bed care providers are technically and allocatively efficient in a specified year.

The technical efficiency concerns the maximization of outputs for the specified level and the combination of inputs, or on the contrary, it regards the minimization of the input utilization for the specified level of outputs. DEA model based on mathematical modeling and multiple criteria decision-making, especially in public health, e.g. Dlouhý, Jablonský (2004), Dlouhý, Novosadová, Jablonský (2007), Butková, Roháčová (2011), Borůvková, Kuncová (2012) and Vaňková, Vrabková (2013, 2014), is appropriate for technical efficiency evaluation.

On the other hand, allocative efficiency reflects maximal outputs for the specified level of input costs, or alternatively minimal costs for the required level of the outputs. Drummond et al (2005) or Ochrana (2005) suggest chiefly various variants of financial analyses, e.g. Cost-Minimization Analysis (CMA), Cost-Effectiveness Analysis (CEA), Cost-Utility Analysis (CUA) or Cost-Benefit analysis (CBA). Above all it is the CBA method that specifies inputs and outputs in monetary units, and which is an appropriate method for measuring the allocative efficiency, thus providing data about adequate amount of investments in health care. In practice, the application of this method is limited though, even though it defines the efficiency of the allocation because it is not determined, or rather it is not possible to determine how to remunerate the highly acknowledged value of the human life, i.e. health.

However, allocative efficiency can generally be approached specifically with regard to the particular production area (e.g. when the efficiency of the hospital bed care is being considered), namely by its own conception of input and output financial parameters of units under investigation (Háva, 2012).

\section{Material and Methods}

\section{Hospital Establishments in the Czech Republic}

It is already well known from Arrow's works (1963) that the health care market differs from standard markets, above all by demand characteristics, expected behavior of physicians, uncertainty of the production effect and by conditions of the supply. The informational asymmetry in the patient - physician relationship is particularly significant. These people are fundamental participants when the health care is being provided and their relationship is considerably specific from several points of view. First of all, the system of public health in the Czech Republic is characteristic by its prescribed source of financing, namely in the form of public health insurance. Expenses spent in healthcare institutions of the Czech Republic were financed from the following sources: $78.8 \%$ from public health insurance, $5.3 \%$ from public budgets (the state budget, regional budgets and local budgets). Private expenses amounted to $15.9 \%$ of the total expenses in 2012 by IHIS CR (2014). Public health insurance covers health services which were provided to the insured in the scale of financing and in conformity with relevant valid legislation. Therefore, the services provided to patients by doctors are financed most frequently by means of the public health insurance, i.e. on the basis of a contract made between the providers of the health care and relevant health insurance company. This general contract is the result of negotiating procedures between the 
groups involved. The profile of the health service being provided is another specific feature. In the Czech Republic, the patient - physician relationship (the health establishment as a provider) is regulated by Act No. 89/2012 Coll., of the Civil Code, and by a specific legal rule for the specified area, namely by Act No. 372/2011 Coll., On health services and the terms and conditions for the providing of such services, as last amended.

The main participants functioning in a potential „,market“ of hospital bed care are: (i.) hospitalized patients (,clients“/ the receivers of the service); (ii.) providers of services of hospital bed care - hospital establishments with a different legal form (e.g. regional allowance organizations); (iii.) health insurance companies paying for the provided hospital bed care to its providers, (iv.) the state as the author and regulator of the health care system and the payer of health insurance contributions at the same time.

The patient is defined as a physical entity to whom health services are provided, in case of this article - the hospital bed care, namely by the health care staff who are the specialists in providing this type of health care. The provider is a physical entity or legal entity that is justified to provide health services by Act No. 372/2011 Coll., on health services and the terms and conditions for providing of such services, as last amended (hereinafter only Health Service Act). The provider in this model is considered a hospital establishment.

The payment for registered health services is secured by insurance payers, i.e. by health insurance companies. It is the so-called third party payer. In the Czech Republic, there is a pluralistic model of health insurance companies. On the one side there is a General Health Insurance Company of the Czech Republic (hereinafter only VZP CR) established by No. 551/1991 Coll., on the other side there are departmental, professional, business and other health insurance companies whose establishment, activities, dissolution and relation to VZP CR is regulated by Act No. 280/1992 Coll. The patient is entitled to choose a health insurance company under $\$ 11$ of Act No. 48/1997 Coll., on public health insurance and on changes to certain related laws, at last amended. The patient - health insurance companies' relationship is defined by the payment of the health insurance contributions for the public health insurance, which means generating the sources for the payment for health services. Health insurance contributions to the public health insurance are redistributed (risk compensation). Payments for health services are tools whose aim is to reinsure to the patient effective and purposeful care, but also to motivate providers to have positive attitudes to their patients. They are related to the process of fund distribution between individual segments and health services providers and they are set annually on the basis of a document called a payment regulation. The regulation No. 428/2013 Coll., on defining the value of points, the level of payments of covered services and regulatory restrictions for year 2014 became effective on January 1, 2014. The reference period is year 2012. The section of the acute bed care includes covering the payment for the DRG production and mechanism. DRG system is a classification and payment system which belongs to the systems denominated as casemix systems. IR-DRG version (International Refined Diagnosis Related Group) is a system which is used in the Czech Republic.

Since 2012 there has been an attempt to unify the conditions for all providers of the acute bed care by putting nearer the rate called a standard rate, which is the next step to 
consolidating the DRG position related to the payments for hospital care (Šedo, 2013). Unification of the standard rate with all health insurance companies in every hospital is one of the priorities of the payment regulation for 2014. The situation of hospital economy in this year was substantially affected by the decision of the Constitutional Court of the Czech Republic Pl. CC 36/11, published in Acts Collection No. 238/2013 Coll., by which the duty to pay regulatory fees for bed care provision, which was CZK 100,under the regulation of Act No. 48/1997 Coll., on public health insurance and on changes to certain related laws, as last amended effective until December 31, 2013, was cancelled and the possibilities of the direct payment of the insured for economically casting variant of treatment were also cancelled. However, the funds of hospitals established by various founders are increased according to the payment regulation for year 2014 (MH CR, 2014).

Hospital bed care services can be characterized chiefly as public services - health services which are entirely or partly financed from public budgets and the public health insurance, and perform tasks in public interest and are controlled and checked by public administration. The legitimate forms of health care are regulated by Act No. 372/2011 Coll., on health services and the terms and conditions for the providing of such services, as last amended, and they are out-patient care, one-day care, in-patient care and health care provided in the patient's own social setting.

The Health Service Act defines bed care as such health care which cannot be provided in an out-patient department. In order to provide this care, it is necessary to hospitalize the patient and the bed care has to be provided continuously in a hospital entitled to provide hospital care. Bed care is generally divided into the intensive bed care, standard bed care, aftercare and long-term bed care.

The selected complex of 17 hospitals takes into consideration the productive homogeneity of the selected units in case of this article. The homogeneity is considered in the prevailing acute bed care of the selected units and their legal form and also the type of the founder - the regional allowance organizations. The choice of the regional allowance organizations was also based on the trend of the number and structure of the legal forms of the hospital establishments in year 2003 - 2012. Figure 1 shows that in 2003, regional allowance organizations were the most frequent hospital establishments in the Czech Republic (81 regional allowance organizations); on the other hand, there were only 23 regional allowance organizations out of which 5 provided aftercare in 2012 . The number of regional allowance organizations has dropped by $72 \%$ in the last 10 years. With these regional allowance hospitals, the legal form was changed mostly into the joint-stock company of the region. This fact is also illustrated in Figure 1. Thus it is possible to assume that current regional allowance organizations have in common the fact that they were also excluded from the privatization conception by individual regional governments. The reasons for this change were economic aims, or efficiency, in other words.

17 hospitals (hereinafter also units) which provide mainly acute care (note - in most cases they dispose of beds intended for acute care) were selected for the purpose of this article. Hospital Tišnov was excluded from the total number of 19 regional allowance organizations because this hospital deals more with aftercare than the acute care. Hospital Nový Jičín, which changed the legal rule in year 2012 and became the joint-stock 
company, was another hospital excluded. It is also necessary to underline the fact that some hospitals provide not only bed care, but also out-patient care, or aftercare in specialized branches.

Figure 1 Trend of the Structure of the Legal Form of Hospitals in the Czech Republic

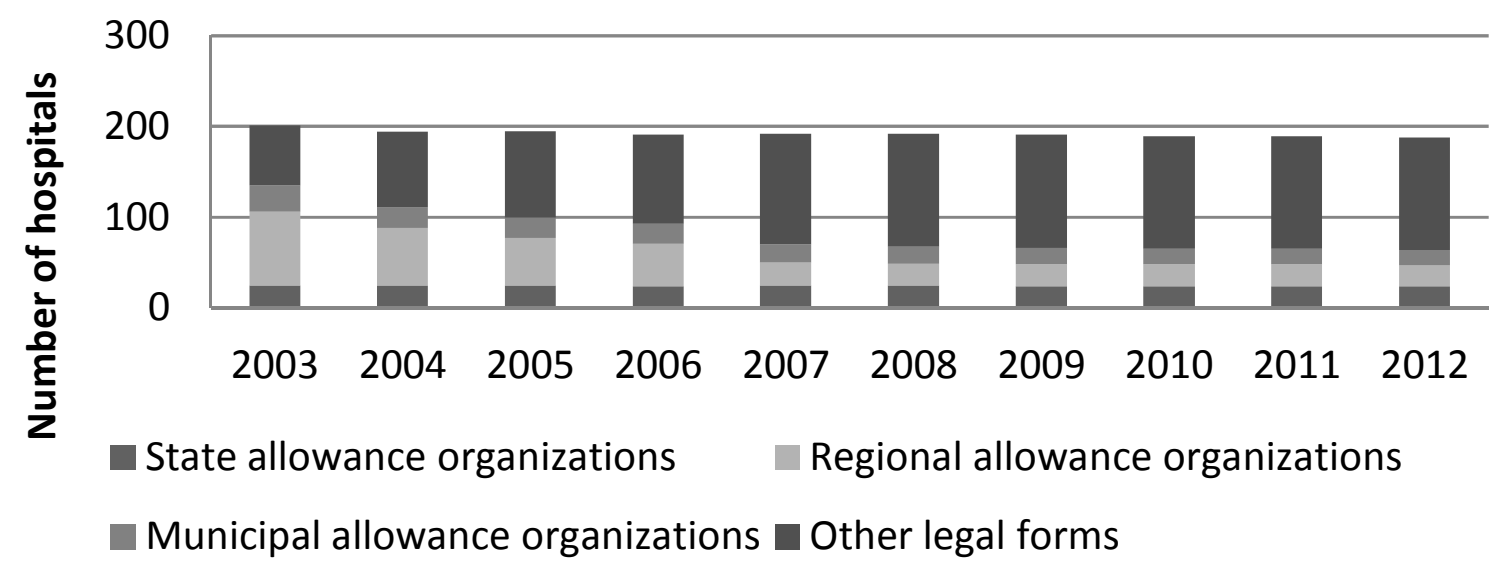

Source: IHIS CZ, 2014.

Until December 31, 2012, there was a total of 188 (of with University hospitals 10, Hospitals 146, Hospitals with chronic beds 32) hospitals in the Czech Republic. Hospitals constitute $77.6 \%$ out of the total number of hospital establishments in the Czech Republic and $12.3 \%$ of hospitals are regional allowance organizations.

The applied model related to economical efficiency consists of the outcome of the technical efficiency comparing selected input and output parameters, and of the outcome of the allocative efficiency which stems from the analysis of the obtained economical results of the selected units.

Number of beds is the central parameter both for expressing the efficiency of selected units and their size in general. The number of beds with the selected units was changing during $2010-2012$ or rather than that, it was decreasing. The sharpest decrease of the bed number in the period of 2010 - 2012 can be seen with Hospital with Outpatient Clinic Karviná-Ráj, and it is the decrease by 147 beds, Hospital Znojmo - by 99 beds, Hospital Třebíč - by 73 beds, and Hospital Břeclav - by 50 beds. The selected units were arranged by the size and grouped to 4 size categories.

- $\quad$ The size category no. I., the number of beds in the range of 650 to over 650,1 hospital - Hospital Jihlava;

- $\quad$ The size category no. II., the number of beds in the range of 501 to 650, 4 hospitals - Hospital Znojmo, Hospital Havlíčkův Brod, Hospital Kyjov, the Silesian hospital in Opava;

- $\quad$ The size category no. III., the number of beds in the range of 351 to 500, 8 hospitals - Hospital Třebíč, Hospital Vyškov, Hospital Břeclav, Hospital with Outpatient Clinic Havírov, Hospital Nové Město na Moravě, Hospital Frýdek-Místek, Hospital with Outpatient Clinic Karviná-Ráj, Hospital Třinec; 
- $\quad$ The size category no. IV., the number of beds in the range of $200-350,4$ hospitals - Hospital Pelhřimov, Associated Medical Equipment Krnov, Hospital Ivančice, TGM Hospital Hodonín.

\section{Methods of Measuring Efficiency}

Generally, it can be stated that efficiency expresses the relation of outputs in the form of services or other products, and the inputs, i.e. the resources used to achieve them (inputs $\mathrm{x}$ outputs). The examples expressing the input and output parameters in terms of hospital establishments within the process-oriented model is illustrated in Figure 2.

Figure 2 The Process-oriented Model of Efficiency Measurement in Terms of Hospital Bed Care

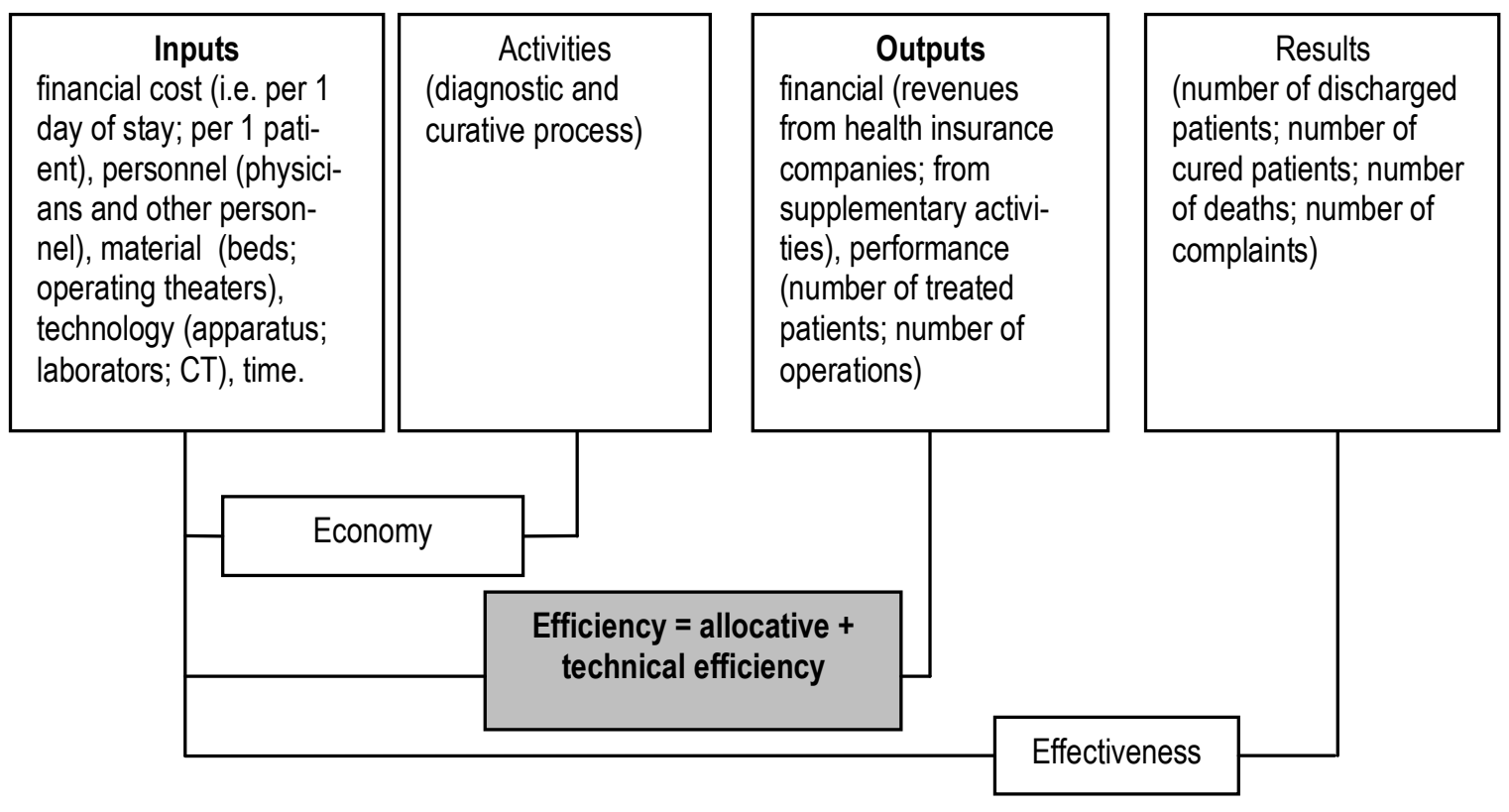

The measurement of technical efficiency is carried out by using the number of methods which include DEA model. This model works with financial and non-financial parameters, or with their combination (e.g. Androutsou, Geitona, Yfantopoulos, 2011; Bates, Mukherjee, Santerre, 2006; Al-Shayea, 2011). In terms of the hospital bed care, the issues of measurement and efficiency evaluation are dealt with for example by Peacock, Chan, Mangolini, Johansen (2001) and Mandl, Diery, Ilzkovitz (2008).

The Data Envelopment Analysis model (see DEA), namely in the form of CCR (named after the authors - Charnes, Cooper and Rhodes, who modified the original Farrel's model) base on the input-oriented model with constant returns to scale was used for the technical efficiency calculation (TE).

CCR DEA maximizes the proportion of the evaluated unit $U_{q}$ expressed as a proportion of weighted inputs and weighted outputs with sticking to the terms and the proportions of efficiency of all the other terms are less or equal 1, i.e. $z=1$. Each unit obtains via weights for inputs $v_{i}=1.2, \ldots, m$, the virtual input and via weights for outputs $u_{i}=$ $1.2 \ldots ., \mathrm{r}$, the virtual output:

- the virtual input $=\mathrm{v}_{1} \mathrm{x}_{1 \mathrm{q}}+\mathrm{v}_{2} \mathrm{x}_{2 \mathrm{q}}+\ldots \ldots+\mathrm{v}_{\mathrm{m}} \mathrm{x}_{\mathrm{mq}}$, 
- $\quad$ the virtual output $=\mathrm{u}_{1} \mathrm{y}_{1 \mathrm{q}}+\mathrm{u}_{2} \mathrm{y}_{2 \mathrm{q}}+\ldots .+\mathrm{u}_{\mathrm{r}} \mathrm{y}_{\mathrm{rq}}$.

The model for unit $U_{q}$ is by the means of Charnes - Cooper transformation transferred from the problem of linear divided programming into the standard problem of programming, which look like (1). It is good for non-effective units that their rate of efficiency is less than one, i.e. $\mathrm{z}<1$.

to maximize

$$
z=\sum_{\mathrm{i}}^{\mathrm{r}} \mathrm{u}_{\mathrm{i}} \mathrm{y}_{\mathrm{iq}}
$$

subject to

$\sum_{i}^{r} u_{i} y_{i k} \leq \sum_{j}^{m} v_{j} x_{j k, k=1,2, \ldots, n,}$
$\sum_{\mathrm{j}}^{\mathrm{m}} \mathrm{v}_{\mathrm{j}} \mathrm{x}_{\mathrm{jq}}=1$

$u_{i} \geq \varepsilon \quad i=1,2, \ldots, r$,

$v_{j} \geq \varepsilon, \quad j=1,2, \ldots, m$.

Analysis related to CCR DEA model required 3 input parameters (in the annex Table I):

- number of beds,

- the average length of stay per a hospitalized patient,

- costs per a day of stay.

Two following parameters were selected to measure the output (in the annex Table II):

- bed occupancy in days,

- number of hospitalized patients.

The input and output data were obtained from the public data base IHIS CR - Kardexes for years 2010, 2011 and 2012.

To define the allocative efficiency of selected hospitals, it was necessary to select the following financial indicators:

- total costs calculated per 1 bed,

- total revenues calculated per 1 bed.

The method of the allocative efficiency evaluation within the scope of this article is made complicated by the restriction which lies in the fact that total costs and total revenues of the selected units cannot distinguish between the in-patient and out-patient care of the unit. The distinction between costs and revenues with respect to the structure of publicly publicized information was not feasible with all the selected units.

The specific values of the selected financial indicators for each of the years in the 2010 - 2012 period are presented in the annex of this article, see Table III., Table IV., and 
Table V. The data indispensable for the allocative efficiency analysis were obtained from the data base of Ministry of Finance of the Czech Republic, ÚFIS (the data about accounting and financial information of the state).

The allocative efficiency (AE) of the particular unit is expressed by index $e$ and proportion of the total costs calculated per 1 bed (TCB) and total revenues calculated per 1 bed (TRB) related to a specific period $t_{m}$, see (2). For allocationally efficient units holds the fact that their rate of efficiency index is less than one, i.e. e $<1$. Provided that index $e=$ 1 , the allocative efficiency of the unit is zero, and provided that $\mathrm{e}>1$, the allocative efficiency of the unit is negative, which means that the unit is allocatively inefficient.

$$
e=\frac{T C B_{t m}}{T R B_{t m}}
$$

The results of the allocative efficiency were subsequently evaluated in connection with:

- revenues from sales of services (payments from health insurance companies) calculated per bed,

- total staff costs (salaries + transfer payments of health insurance contributions per an employee) calculated per bed,

- economic outcome.

Figure 3 The Allocative Efficiency of Selected Units in the Period of 2010 - 2012

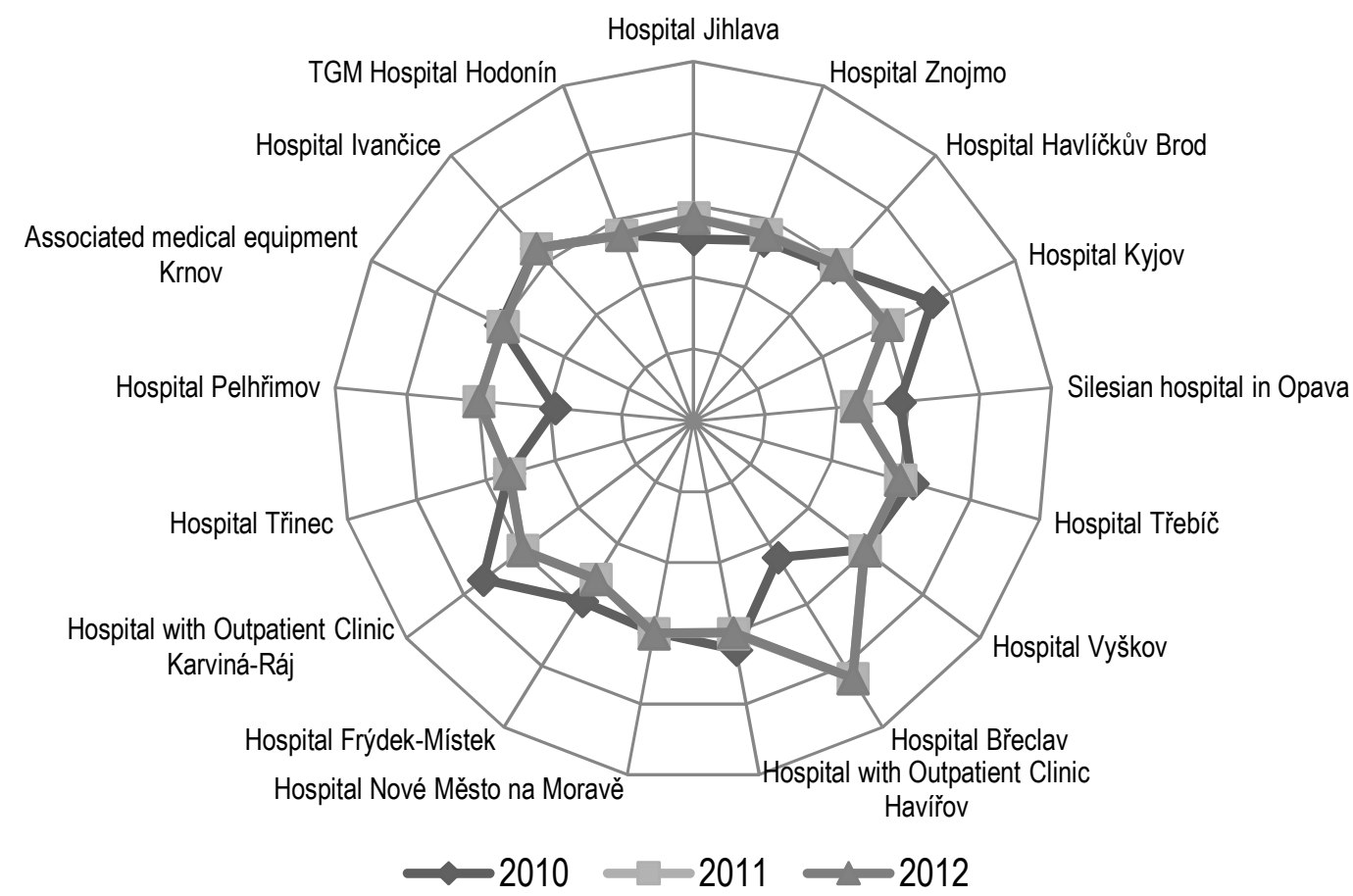




\section{Results and Discussion}

The allocative efficiency in the period 2010 - 2012 with selected 17 units was evaluated by actual/resulting values of index $e$ by the proportion of total costs calculated per 1 bed, and total revenues calculated per 1 bed. The unit is allocatively efficient when its index $e$ is less than $1(\mathrm{e}<1)$. The results are presented in Table 1 . In all years under observation, Hospital Jihlava, Hospital Znojmo, the Silesian Hospital in Opava, Hospital Třinec and TGM Hospital Hodonín can be considered allocativelly efficient.

AE has a decreasing tendency with the units under investigation. In 2010 there were 47\% (8 out of 17) of allocatively efficient hospitals being examined. However, in years 2011 and 2012 it was only 35\% (6 out of 17). Figure 3 monitors this trend. The decreasing AE points out the declining capability of the units to produce

a positive economic result.The results of the technical efficiency analysis (TE) via DEA model oriented to input and constant returns to scale during years $2010-2012$ with the selected 17 units are presented in Table 1 . The technically efficient units are when $\mathrm{z}=1$ in the year under investigation.

In the monitored years 2010 - 2012 the following units (hospitals) were efficient: Hospital Jihlava, Hospital Kyjov, the Silesian hospital in Opava, Hospital Břeclav, and TGM Hospital Hodonín. This finding implies that in relation to achieved outputs - bed occupancy in days and number of hospitalized patients, these units efficiently use their inputs, i.e. number of beds, average length of stay per a hospitalized patient and costs per a day of stay, . On the contrary, the technically inefficient units - Hospital Třebíć, Hospital with Outpatient Clinic Havírov, Hospital Frýdek-Místek, Hospital with Outpatient Clinic Karviná-Ráj, Hospital Pelhřimov, Hospital Ivančice and even Associated Medical Equipment Krnov, exploit their input in an inefficient way in all the monitored years, see Figure 4. For example, high costs per day of stay (CZK 5990,- in 2012) with Hospital with Outpatient Clinic Karviná-Ráj and the average length of stay per the hospitalized patient (8 days in all the years) with Hospital Pelhřimov are weak points of the subject in question. 
Figure 4 Technical Efficiency of Selected Units in the Period 2010 - 2012

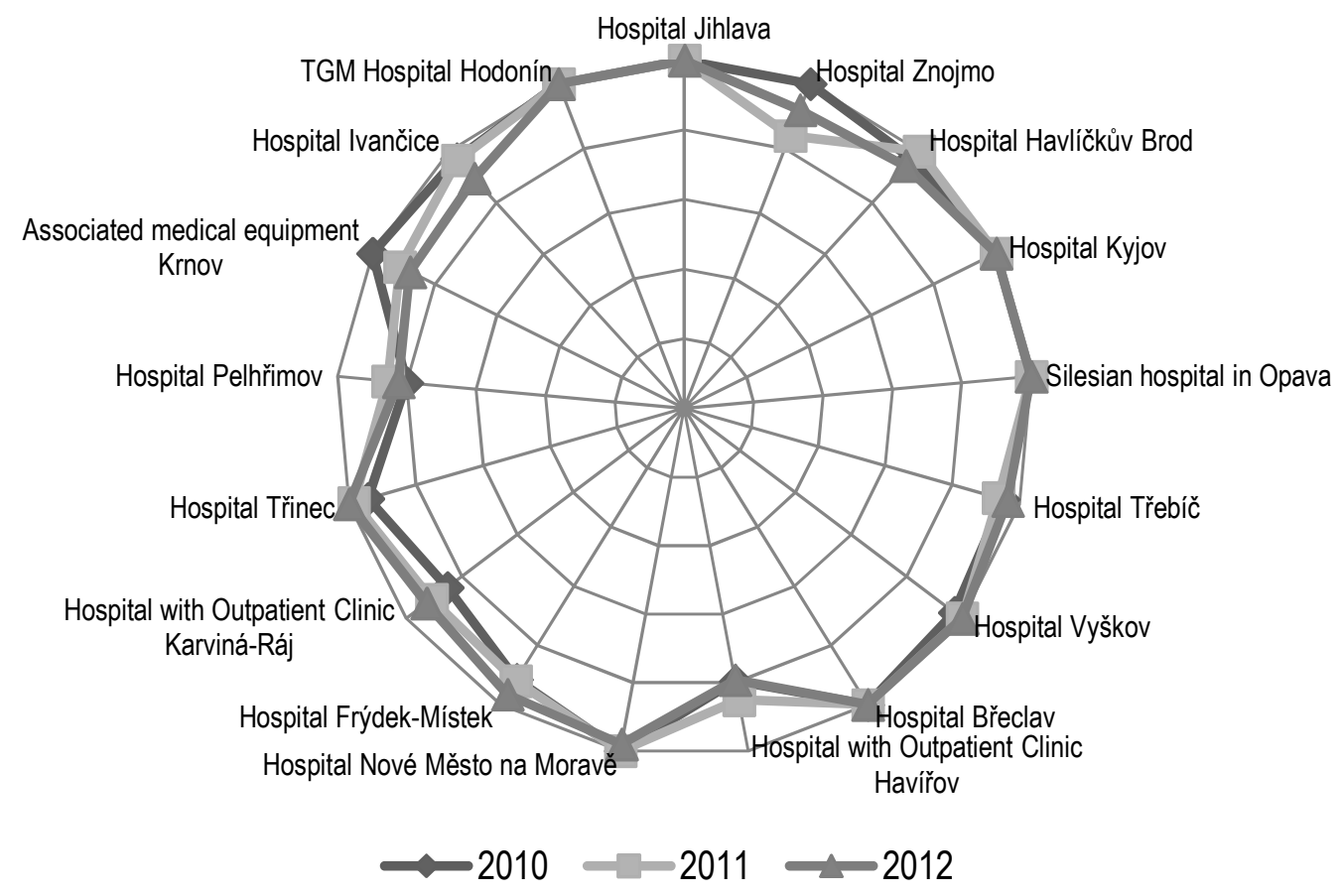

In connection to the above-mentioned findings it is, however, necessary to point out that the identification of all the causes of inefficiency, based on the analysis of DEA model, is difficult due to many different aspects involved. Those causes have to be revealed and subsequently analyzed by a particular management of a hospital. The question remains whether reducing number of beds is enough to achieve increase of hospital inefficiency. The examples of the analyzed hospitals do not prove this thesis, see Hospital with Outpatient Clinic Karviná-Ráj or Hospital Třebíč. This implies a logical assumption that reducing number of beds has to go hand in hand with reducing both variable and fixed costs of the hospital within a longer stretch of time. Hospital Třinec is a good example when it comes to this subject. Even with this hospital the gradual improvement of the technical efficiency is evident. Hospital Trinec reduced the number of beds by $8 \%$ during the monitored years, the average length of stay per the hospitalized patient decreased by $11 \%$, while costs per day of stay rose just by CZK 30,-.

The economic efficiency of hospital bed care providers (units) that was monitored over years $2010-2012$ is summed up in Table 1 .

Economically efficient units are those that are allocatively efficient $(\mathrm{e}<1)$, and also technically efficient $(\mathrm{z}=1)$ in a given year. The evaluation implies the fact that economically efficient units totaled to $17.6 \%$ (3 out of 17) in 2011 and $23.5 \%$ (4 out of 17) in 2012. In the years under observation, Silesian Hospital in Opava, Hospital Jihlava and TGM Hospital Hodonín can be considered economically efficient units. 
Table 1 Results of Economic Efficiency of Units Under Observation in the Period 2010 2012

\begin{tabular}{lccccccc} 
& \multicolumn{2}{c}{2010} & \multicolumn{2}{c}{2011} & \multicolumn{2}{c}{2012} \\
& AE $(\mathrm{e})$ & $\mathrm{TE}(\mathrm{z})$ & $\mathrm{AE}(\mathrm{e})$ & $\mathrm{TE}(\mathrm{z})$ & $\mathrm{AE}(\mathrm{e})$ & $\mathrm{TE}(\mathrm{z})$ \\
\hline Hospital Jihlava & 0.98 & 1 & 0.99 & 1 & 0.99 & 1 \\
\hline Hospital Znojmo & 0.98 & 1 & 0.99 & 0.84 & 0.99 & 0.92 \\
Hospital Havlíčkův Brod & 0.99 & 0.97 & 1.00 & 1 & 1.00 & 0.94 \\
Hospital Kyjov & 1.04 & 1 & 1.00 & 1 & 1.00 & 1 \\
Silesian hospital in Opava & 0.99 & 1 & 0.96 & 1 & 0.96 & 1 \\
\hline Hospital Třebíč & 1.01 & 0.95 & 1.00 & 0.94 & 1.00 & 0.97 \\
Hospital Vyškov & 1.00 & 0.97 & 1.00 & 1 & 1.00 & 1 \\
Hospital Břeclav & 0.96 & 1 & 1.06 & 1 & 1.06 & 1 \\
Hospital with Outpatient Clinic Haviřov & 1.01 & 0.80 & 1.00 & 0.85 & 1.00 & 0.79 \\
Hospital Nové Město na Moravěn & 1.00 & 1 & 1.00 & 1 & 1.00 & 0.98 \\
Hospital Frýdek-Místek & 1.00 & 0.91 & 0.98 & 0.92 & 0.98 & 0.97 \\
Hospital with Outpatient Clinic Karviná-Ráj & 1.03 & 0.85 & 1.00 & 0.91 & 1.00 & 0.93 \\
Hospital Třinec & 0.98 & 0.94 & 0.98 & 0.99 & 0.98 & 1 \\
\hline Hospital Pelhřimov & 0.95 & 0.80 & 1.00 & 0.85 & 1.00 & 0.82 \\
Associated Medical Equipment Krnov & 1.00 & 1 & 1.00 & 0.91 & 1.00 & 0.88 \\
Hospital Ivančice & 1.01 & 0.97 & 1.01 & 0.97 & 1.01 & 0.89 \\
TGM Hospital Hodonín & 0.99 & 1 & 0.99 & 1 & 0.99 & 1 \\
\hline
\end{tabular}

Figure 5 Total Revenues in Relation to Revenues From Sales of Services Calculated Per Bed in $2010-2012$

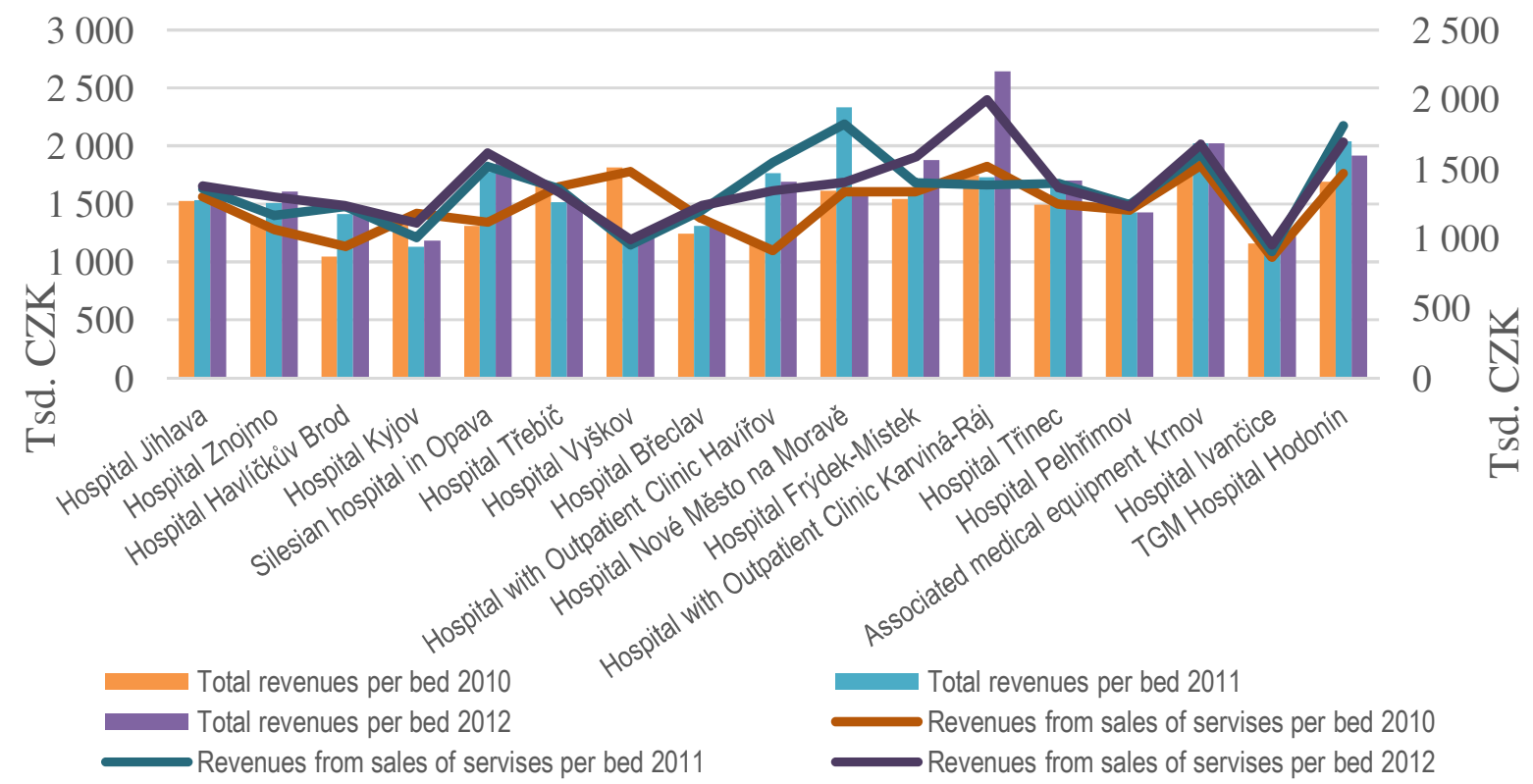

Furthermore, we have analyzed total cost in relation to total staff costs per bed in 2010 2012 (see Figure 6). This analysis indicates that the development and state of total costs is significantly related (correlation coefficient in $2010-0.88 ; 2011-0.92$, and 0.95 in 2012) to the development and state of total staff costs. 
The economically efficient units (a) recovered revenues from sales of services at a stable amount (i.e. $85-88 \%$ out of the total revenues of units); (b) showed constant staff costs over all the years; and (c) aggregated a positive income during all years under investigation.

From the units size point of view (the size was examined only within the year 2012) it can be stated that size defined by number of beds does not have any provable impact on achieving economic efficiency of the units studied. Nevertheless, this finding does not deny the premise that bigger units (hospitals with higher number of beds) tend to have more favorable conditions for achieving economic efficiency (see Hospital Jihlava).

The relation between every aspect of the economic efficiency recorded in Table 1 is as follows:

- in $2010-62.5 \%$ of technically efficient hospitals are allocatively efficient as well;

- in $2011-37.5 \%$ of technically efficient hospitals are allocatively efficient as well;

- in $2012-57.1 \%$ of technically efficient hospitals are allocatively efficient as well.

The evaluation conducted with the hospitals under examination also implies the statement that allocation efficiency is getting worse considerably. If 4 hospitals in 2010 showed $\mathrm{AE}=1$ (i.e. neither efficient nor inefficient), then there were already 9 hospitals with this result in 2011 and 2012.

\section{Conclusion}

Hospitals are, as a rule, defined as the health-service institutions that provide the health care to the patients that cannot be cured in an outpatient department. These institutions hospitals have a set number of beds, health-care staff with required qualification and they are capable to provide the hospital / in-patient care continuously. Hospitals can be differentiated e.g. by the type of ownership, prevailing kind of provided care, average length of stay, or the extent of bed fund. In the Czech Republic, the form, specialization, the number and equipment of hospitals are the result of the execution of a political decision-making procedure that also defines organizational and legal framework and rules for financial flows in the market of the hospital bed care. The market of hospital bed care working under public sector conditions is specific in the fact that besides supply (hospitals) and demand (hospitalized patients), there is the third party which plays the role of the payer (health insurance companies). The state plays the role of the owner of hospital establishments and controller of this specific market structure. As a result, indirect price fixing of hospital bed care and indirect payment for its provision in practice cause complications of economical nature to all parties involved, first of all to hospitals. For this reason it is also difficult to monitor and evaluate the economic efficiency of hospital establishments. A possibility in this sense is offered by evaluation of input and output parameters of technical and financial nature. 
This article evaluated economic efficiency of hospital bed care on an example of 17 selected regional allowance organizations over the period of $2010-2012$. Technical and allocative efficiency are starting points of the economic efficiency. The technical efficiency was evaluated via input and output indicators by the means of DEA model and the variant focusing on inputs and constant returns to scale of the monitored hospitals. Evaluation of the allocative efficiency was carried out by application of its own algorithm that was defined as the proportion of total costs calculated per bed and total revenues calculated per bed. It is also necessary to add that evaluation of efficiency of the studied units can be approached on the basis of further rational economical indicators, such as 1 day of stay or 1 hospitalized patient.

The implemented evaluation implies that only 3 hospitals - the Silesian Hospital in Opava, Hospital Jihlava and TGM Hospital Hodonín - were economically efficient during all the years covered in the period from 2010 to 2012. To be more precise, it was 5 hospitals in 2010, 3 hospitals in 2011, and 4 hospitals in 201. Another conclusion can be drawn from the above-mentioned evaluation and it is the fact that most individual aspects of the economic efficiency mutually complement with the majority of hospitals under investigation. This finding is supported by situation 1 presented in Table 1 which shows that the same hospital is technically efficient and at the same time allocatively efficient in a particular year. In general, there is a declining trend related to allocative efficiency. In 2010, $47 \%$ of the monitored hospitals were allocatively efficient, however, it was only $35 \%$ of the total number of the hospitals under investigation in 2011 and 2012. On the other hand, the number of hospitals entirely allocatively inefficient also dropped from 5 hospitals in 2010 to 2 hospitals in years 2010 and 2012. In 2012, most hospitals (53\%) scored results which can be considered as neither efficient allocatively, nor inefficient, and this fact may signify a considerable risk towards the future. It might occur especially in the situations in which hospitals will have to deal with both expenses connected with inevitable capital investments and expenses caused by changes of legislative conditions, e.g. related to the application of new Civil Code or also with remuneration regulations.

The least important factor from the selected factors under investigation being verified and influencing the economic efficiency is the size of the hospital establishments which is defined by the number of beds. On the other hand, average length of stay per the hospitalized patient is the most important factor. This indicator indicates productivity of the bed fund and also to the nursing staff. However, it is necessary to stipulate the type of hospital bed care, i.e. to distinguish between acute care and aftercare. The aftercare assumes longer hospitalization of patients. This fact was taken into consideration with 17 selected hospital establishments which were the subject of the above-mentioned evaluation.

Based on the evaluation above, it can be stated that the length of hospitalization of a patient is tightly connected to both the cost for the health care and the amount of revenues from health insurance companies, which represent payments for the provided health care. Unjustified length of patient's hospitalization is the source of significant economic risks, i.e. risks of lower revenues from health insurance companies and higher variable costs spent, first of all, on the staff needed for securing the bed care. 
The economic efficiency of acute bed care is tightly connected to the DRG system. In the Czech Republic, the classification DRG system, especially IR-DRG which deals with cost efficiency of acute in-patient care, has been gradually implemented into the reimbursement intimations since 2007. Its role was gradually increasing and in 2012, it finally substituted financing of acute in-patient care by the means of DRG - based case payments (DRG alfa, or DRG beta). The system assumes, among others, that the inpatient care provider will be motivated to shorten the length of hospitalization. The above-mentioned facts assume that the acute bed care establishments will be pushed more and more to decreasing the number of days of hospitalization.

\section{References}

AL-SHAYEA, A. M. (2011). Measuring hospital's units efficiency: A data envelopment analysis approach. International Journal of Engineering \& Technology IJET-IJENS 11: 06.

ANDROUTSOU, L., GEITONA, M., YFANTOPOULOS, J. (2011). Measuring Efficiency and Productivity Across Hospitals in the Regional Health Authority of Thessaly, in Greece. Journal of Health Management. 13: 121-140, 2011.

ARROW, K. (1963). Uncertainty and the welfare economics of medical care. American Economic Review. 53, (5): 941 - 973.

BATES, L., MUKHERJEE, K., SANTERRE, R., E. (2006). Market Structure and Technical Efficiency in the Hospital Services Industry: A DEA Approach. Medical Care Research and Review. 63: 499-524, 2006.

BORU゚VKOVÁ, J., KUNCOVÁ, M. (2012). Porovnání očních oddělení nemocnic Kraje Vysočina pomocí DEA modelů. Acta Oeconomica Pragensia. 12 (5): 75-84.

BUDKOVÁ, J., ROHÁČOVÁ, V. (2011). Hodnotenie efektívnosti poskytovatel'ov zdravotnej starostlivosti v Českej republike. Teoretické a praktické otázky veřejné ekonomiky a správy. Ostrava: VŠB-TU Ostrava.

DARMOPILOVÁ, Z. (2012). Role plátce ve zdravotním systému. Zdravotnictví v $\check{C} R$. No 3 - 4/XV/2012. pp. 12-16.

DOOREN, W., BOUCKAERT, G. and J. HALLIGAN, (2010). Performance Management in the Public Sector New York: Routlege.

DLOUHÝ, M., NOVOSADOVÁ, I, JABLONSKÝ, J. (2007). Využití analýzy obalu dat pro hodnocení efektivnosti českých nemocnic. Politická ekonomie. 2007 (1): 60-71

DLOUHÝ, M., JABLONSKÝ, J. (2004). Modely hodnocení efektivnosti produkčních jednotek. Praha: Professional.

DRUMMOND, M., F., SCULPHER, M., J., TORRANCE, G., W., O’BRIEN, B., J., and G., L., STODDART. (2005). Methods for the Economic Evaluation of Health Care Programmes. 3th ed. Oxford University Press.

FLYNN, N. (2012). Public Sector Management. 6th ed. London: SAGE Publications.

HOLLINGSWORTH, B., PEACOCK, S. J. (2008). Efficiency Measurement in Health and Health Care. London: Routledge. 
HÁVA, P. (2012). Úhrady nemocní péče v ČR. Zdravotnictví v České republice. No 2/XV/2012, pp. 20-33.

MANDL, U., DIERX, A., ILZKOVITZ, F. (2008). The effectiveness and efficiency of public spending. European Economy. Economic Papers 301. Brusels: European Commission.

MINISTRY OF HEALTH (2014). Nemocnicím přidá ministerstvo spravedlivě. Retrieved January, 2014, from http://www.mzcr.cz

OCHRANA, F. (2005). Nákladově užitkové metody ve veřejném sektoru. Praha: Ekopress.

IHIS CZ (2014). Ekonomické výsledky nemocnic 2010-2012. Retrieved January, 2014, from http://www.uzis.cz

IHIS CZ (2014). Lůžková péče 2010-2012. Retrieved January, 2014, from Dostupné: http://www.uzis.cz

ÚFIS, Ministerstvo financí ČR (2014). Retrieved January, 2014, from http://wwwinfo.mfcr.cz/cgi-bin/ufis/iufisusc/index.pl

Národní program reforem České republiky (2012). Investice pro evropskou konkurenceschopnost: Př́spěvek České republiky ke Strategii Evropa 2020. Retrieved December, 2013, from http://ec.europa.eu/europe2020/pdf/nd/nrp2012_czech_cs.pdf

ŠEDO, J. (2013). DRG v praxi. Seznámení s českou implementací úhradového systému $D R G / 2013$. Galén, Praha.

VAŇKOVÁ, I, VRABKOVÁ, I. (2013). Možnosti měření efektivnosti akutní lůžkové péče. Konferenční př́íspěvek. Veřejná ekonomika a správa 2013. Ostrava: VŠB-TU Ostrava.

VRABKOVÁ, I, VAŇKOVÁ, I. (2014). Evaluation of Efficiency of In-patient Care in Hospitals using Data Envelopment Analysis Model. Current Trends in Public Sector Research. Proceedings of the 18 th International Conference. Brno: Masaryk University, pp. 371-379.

Act No. 89/2012 Coll., by Civil Code, as last amended.

Act No. 48/1997 Coll., on public health insurance and on changes to certain related laws, as last amended.

Act No. 372/2011 Coll., on health services and the terms and conditios for the providing of such services, as last amended.

Act. No. 551/1991 Coll., on the General Health Insurance Company of the Czech Republic, at last amended.

Act. No. 280/1992 Coll., on departmental, professional, business and other health insurance companies, as last amended. 